\title{
JUURNAL.RU
}

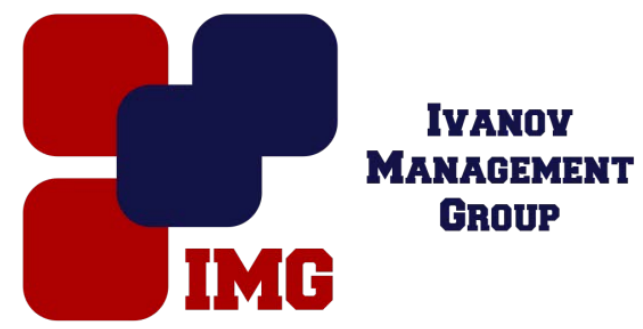

Алисеенко Е.М., Ковалев В.Н.
ФГБОУ ВПО филиал БГУ им. И.Г. Петровского в г. Новозыбкове
Новозыбков, Россия

doi: 10.18411/lj-25-12-2016-2-07

idsp 000001:lj-25-12-2016-2-07

\section{Методы формирования познавательной компетентности на уроках физики}

Требования к современным технологиям обучения состоят в индивидуализации процесса обучения, повышении роли самостоятельности учащихся в приобретении новых знаний. Ведь потеря интереса к обучению на каком-то этапе порождает нежелание учащихся изучать какой-либо предмет, а это приводит к тому что учащийся, не усвоив одну тему, а за ней-другую, не понимает предмет. Поэтому так важно строить урок интересным, а содержание современным, так чтобы ученик сам стремился познать что-либо новое в данном предмете или даже в целом направлении какого-либо знания.

Самостоятельность - понимается как, способность человека без посторонней помощи ставить цели, мыслить, действовать, ориентироваться в ситуации. Пустовойтов В.Н. отмечал что: «Познавательная компетентность старшеклассника понимается как личностный опыт учащегося в сфере саморегулируемой познавательной деятельности, интегральная качественная характеристика личности старшеклассника, отражающая его стремление и способность накапливать и реализовывать свой потенциал в сфере самостоятельной познавательной деятельности для успешного решения личностно-значимых (в том числе-учебных) задач.» Воровщиков С.Г. определяет учебно-познавательную компетентность как «владение учащимися комплексной процедурой, интегрирующей совокупность взаимосвязанных смысловых ориентаций, знания и умений и позволяющей эффективно осуществлять самоуправляемую деятельность по решению реальных учебнопознавательных проблем.» [2]

Основным требованием общества к современной школе является формирование личности, которая умела бы самостоятельно творчески решать научные, производственные, общественные задачи, критически мыслить, вырабатывать и защищать свою точку зрения, свои убеждения, систематически и непрерывно пополнять и обновлять свои знания путем самообразования, 
совершенствовать умения, творчески применять их в действительности. Все это и является задачей учителя.

Для формирования целостной и гармоничной личности необходимо систематическое включение ее в самостоятельную и творческую деятельность, которая выполняется в особой форме работ - самостоятельных работ.

Курс физики в средней школе подразумевает освоение учащимися определенного объема знаний, умений и навыков, что невозможно без самостоятельной работы. Речь идет не только о самостоятельном выполнении учащимися домашних заданий, но и о самостоятельности в поисках и обработки информации, самостоятельности мышления, самостоятельности наработки навыков решения задач.

Поэтому одна из основных задач учителя - организация работы всего класса таким образом, чтобы ученики не только работали самостоятельно, но и делали это с определенной степенью ответственности, а для этого необходимо использовать дифференцированный подход в определении задания для самостоятельного обучения.

В процессе обучения физике применяются различные виды самостоятельной работы, с помощью которых ученики самостоятельно овладевают ЗУН. Виды самостоятельной работы, применяемые в учебном процессе, можно классифицировать по различным признакам:

- по дидактическим целям,

- по уровню самостоятельности учащихся,

- по степени идивидуализации,

- по форме выполнения,

- по месту выполнения.

Активные методы обучения это способы активизации учебнопознавательной деятельности учащихся, которые побуждают их к активной мыслительной и практической деятельности в процессе овладения материалом. Основная задача учителя организовать самостоятельную деятельность учащихся. Основные методы обучения предполагают использование такой системы методов, которая направлена главным образом, не на изложение учителем готовых знаний и их воспроизведение, а на самостоятельное овладение учащимися знаний в процессе активной познавательной деятельности.

Наиболее современные, на наш взгляд, методы формирования познавательной компетентность это:

\section{1.Учебно-исследовательская деятельность учащихся.}

Исследовательская деятельность учащихся - образовательная технология, использующая в качестве главного средства учебное исследование. Исследовательская деятельность предполагает выполнение учащимися учебных исследовательских задач с заранее неизвестным решением, направленных на создание представлений об объекте или явлении окружающего мира, под руководством учителя. 
Учебное исследование - образовательный процесс, реализуемый на основе технологии исследовательской деятельности. Его основные характеристики: 1) выделение в учебном материале проблемных точек, предполагающих вариативность; специальное конструирование учебного процесса «от этих точек» или проблемная подача материала; 2) развитие навыка формулирования гипотез; 3) обучение работе с разными версиями на основе анализа свидетельств или первоисточников (методики сбора материала, сравнения и др.); 4) знакомство с первоисточниками; 5) развитие навыков анализа и выбора одной версии в качестве истинной.

Главной целью исследовательской работы школьников является развитие их способности критически мыслить, формулировать проблему, искать её решение. Эти цели достигаются наилучшим образом, если ученику создаются условия для самостоятельной постановки задач исследования, выбора объекта, анализа и т.д. Очевидным становится то, что на каждом этапе нужно дать учащемуся определённую свободу в работе, иногда даже в ущерб методике, иначе исследование может постепенно превратиться в последовательность стандартных учебных этапов.

\section{2.Использование метода кейс-технологий.}

Кейс это - описание конкретной реальной ситуации, подготовленное по определенному формату и предназначенное для обучения учащихся анализу разных видов информации, ее обобщению, навыкам формулирования проблемы и выработки возможных вариантов ее решения в соответствии с установленными критериями.

Кейсовая технология (метод) обучения - это обучение действием. Суть кейс-метода состоит в том, что усвоение знаний и формирование умений есть результат активной самостоятельной деятельности учащихся по разрешению противоречий, в результате чего и происходит творческое овладение профессиональными знаниями, навыками, умениями и развитие мыслительных способностей. Кейс-метод - это ситуативная методика, которая позволяет увидеть неоднозначность решения проблем в реальной жизни.

\section{3.Использование метода проектов.}

Метод проектов - это способ достижения дидактической цели через детальную разработку проблемы (технологию), которая должна завершиться вполне реальным, осязаемым практическим результатом, оформленным тем или иным образом (проф. Е. С. Полат); это совокупность приёмов, действий учащихся в их определённой последовательности для достижения поставленной задачи - решения проблемы, лично значимой для учащихся и оформленной в виде некоторого конечного продукта.

Главной отличительной особенностью метода проектов является обучение на активной основе, через целесообразную деятельность ученика, которая соответствует его личным интересам.

В основе этого метода лежит развитие познавательных навыков учащихся, умений самостоятельно конструировать свои знания, умений ориентироваться в 
информационном пространстве, развитие критического и творческого мышления

Метод проектов всегда ориентирован на самостоятельную деятельность учащихся - индивидуальную, парную, групповую, которую учащиеся выполняют в течение определенного отрезка времени. Этот метод органично сочетается с групповым. Метод проектов всегда предполагает решение какой-то проблемы. Решение проблемы предусматривает, с одной стороны, использование совокупности, разнообразных методов, средств обучения, а с другой, предполагает необходимость интегрирования знаний, умений применять знания из различных областей науки, техники, технологии, творческих областей.

\section{Литература}

1. Подласый, И. П. Педагогика: Общие основы. Процесс обучения, книга 1 М.:ВЛАДОС, 2001. - 576 с.

2. Пустовойтов В.Н. Методика формирования познавательной компетентности старшеклассников на уроках математики и информатики: учебное пособие.-Брянск: ООО «Ладомир», 2012.-119с

3. Сластенин, В.А. Педагогика / В. А. Сластенин, И. Ф. Исаев, Е. Н. Шиянов. - М.: Академия, 2002. - 240 с. 